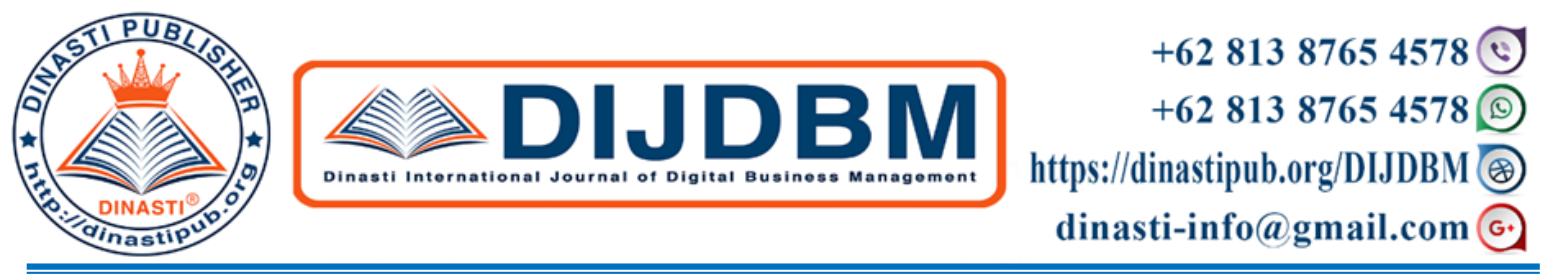

\title{
SENSE AND THINK MARKETING IMPLICATIONS
}

\author{
Runggu Besmandala Napitupulu ${ }^{1)}$, Nandan Lima Krisna ${ }^{2)}$, Lilis Suriani Gultom ${ }^{3)}$ \\ ${ }^{1)}$ Lecturer, Economics Faculty, Universitas Darma Agung, Medan, Indonesia \\ ${ }^{2)}$ Lecturer, Economics and business Faculty, Universitas Persada Indonesia Y.A.I, Jakarta, \\ Indonesia \\ ${ }^{3}$ Lecturer, Agriculture Faculty, Universitas Darma Agung, Medan, Indonesia
}

\begin{tabular}{|c|c|}
\hline $\begin{array}{c}\text { Corresponding author: Firs } \\
\text { Author } \\
\text { E-mail: } \\
\text { rb.napitupulu@gmail.com } \\
\text { lilis04jun@ gmail.com }\end{array}$ & $\begin{array}{l}\text { Abstract: This research is designed to find out and } \\
\text { analyze the implications of sense and think } \\
\text { marketing for customer satisfaction and their } \\
\text { repurchase intention. The object is a vivo } \\
\text { smartphone and respodents are the adult population } \\
\text { in Medan who have made a repeat purchase. The } \\
\text { analysis technique uses structural equation models. } \\
\text { The results showed that marketing sense had a } \\
\text { significant effect both on customer satisfaction and } \\
\text { repurchase intentions; Think marketing has } \\
\text { unsignificant effect on both satisfaction and } \\
\text { repurchase intentions; Consumer satisfaction has a } \\
\text { significant effect on repurchase intentions; Sense } \\
\text { and think marketing simultaneously influence } \\
\text { customer satisfaction; Sense marketing, think } \\
\text { marketing, and satisfaction simultaneously effect } \\
\text { on repurchase intentions for vivo smartphones in } \\
\text { Medan. } \\
\text { Keywords: Consumer Satisfaction, Repurchase } \\
\text { Intention, Sense Marketing, Think Marketing }\end{array}$ \\
\hline
\end{tabular}

\section{INTRODUCTION}

Smartphone users have increased worldwide from year to year. Indonesia is the fourth most active smartphone user country in the world after China, India and the United States. Smartphone on the Indonesian market consists of various brands such as Vivo, ASUS, Samsung, Smartfren, Lenovo, Advan, Xiaomi, and Realme. In Q2 2019, Samsung still dominated the market in Indonesia with the largest market share of $27 \%$. Xiaomi's position with a market share of $21 \%$ is second. Oppo is in third place with a market share of $17 \%$. The fourth place is occupied by Vivo who has a market share of $9 \%$. The fifth position is occupied by Realme with a market share of $8 \%$ (Yusuf, 2019).

Sales of vivo brand smartphones in North Sumatra are still concentrated in retail stores in Medan city. The number of authorized retailers is now in North Sumatra as many as 31 units. The retailers are in Medan as many as 17 units, others are located in regencies / municipalities in north Sumatra. Vivo smartphone sales in North Sumatra also come from online stores such as Bukalapak, blibli.com, shopee, and jd.id. (Vivo 
Store in North Sumatra, 2020). A preliminary survey of 108 smartphone users in Medan showed $21.30 \%$ using vivo, $12.96 \%$ of Xiaomi users, $27.78 \%$ of Oppo users, $9.26 \%$ of realme users, $2.78 \%$ of ASUS users, $17.59 \%$ of Samsung users, $0.93 \%$ of smartfren owners, $1.85 \%$ of Lenovo owners, other brand users as much as $5.56 \%$. Oppo turned out to be the most satisfying brand (29.63\%). Followed by Samsung with the number of $28.70 \%$. Vivo smartphone is third (17.59\%). The fourth sequence is occupied by xiaomi $(11.11 \%)$. The highest repurchase intention is owned by oppo of $25.93 \%$. Samsung was second ranks at $25.00 \%$. Vivo came in third at $24.07 \%$

The consumer is a rational person besides an emotional person (Kertajaya, 2004). So a customer can be satisfied because of cognitive aspects and affective aspects (emotions). The results of previous studies show there are gaps in research findings.

The findings concluded that only sense and feel experiences are positively related to Customer satisfaction (Alkilani et al., 2012). This means that in this study, think marketing does not affect on consumer satisfaction. Other studies reveal that marketing sense has no significant effect on consumer satisfaction (Indrawati \& Fatharani, 2016). The variable of think has a significant negative influence on customer satisfaction (Dian, 2018). One study said, T test results showed that the sense and think variables had a positive and significant impact on customer satisfaction (Zahri et al., 2019).

Several studies have shown that Sense Experience has no effect on consumer repurchase intention (Lamongi et al., 2018; Ong, 2017). Other studies said sense and think marketing partially influence repurchase intentions (Amelia, 2017; Putri et al., 2020).

Some researchers conclude that consumer satisfaction has a positive and significant effect on repurchase intentions (Mohamed, 2014; Suandana et al., 2016). In other studies the results obtained where shopping satisfaction does not have a significant effect on repurchase intentions (Juniwati, 2015).

\section{LITERATURE REVIEW \\ Repurchase intention}

Repurchase intention is a consumer commitment that is formed after the consumer makes a purchase of a product or service (Jessica, 2005). Repurchase intention is a purchase interest that is based on past purchase experiences (Abdullah, 2012). Consumer experience related to products consumed or used can give a good or bad impression. A good impression will satisfy them. A strong desire will arise to buy more goods or brands. Repurchase intention is the determination to buy again the same product or brand based on good consumer experience. Repurchase interest can be identified through the following indicators: Transactional interest, that is a person's tendency to buy a product; Refrential interest, namely a person's tendency to refer products to other people; Preferential interest, that is, an interest that describes the behavior of someone who has the main preference on the product. This preference can only be replaced if something happens with the preference product; Explorative interest, this interest illustrates the behavior of someone who is always looking for information about the product he is interested in and is looking for information to support the positive qualities of the product (Ferdinand , 2000).

\section{Consumer Satisfaction}

Satisfaction is a very important aspect of consumer behavior. Consumer satisfaction is a full evaluation, which results from specific purchase selection (Tjiptono, 2014). Consumers buy a product after first choosing an alternative. Goods used, then evaluated. Finally, consumers evaluate. The realization can be as expected or 
not as expected. If expectations are fulfilled, then satisfied, otherwise not satisfied.

Satisfaction is a feeling of pleasure or disappointment someone who arises because of comparing the perceived performance of their expectations (Kotler dan Keller , 2012). Consumer satisfaction occurs when customer expectations are in line with or can be met by performance or close to being met or can even exceed customer expectations.

Consumer satisfaction is the result of consumers' assessment of goods or services that are purchased or consumed after comparing their realization with their standards. Consumers will feel satisfied if appropriate or above standards, otherwise consumers are disappointed.

Indicators to measure customer satisfaction are: Buy back, Tell good things to others, Pay less attention to other brands, and buy other products from the same company

\section{Sense Marketing}

Sense marketing creates sensory experiences through sight, sound, touch, taste, and smell (Schmitt, 1999). Specific marketing is based on experience arising from the consumer's five senses namely through the eyes (eyesight), ears (hearing), skin (touch), tongue (taste), and nose (smell). Sensory Marketing is a strategy of engaging the senses to sell products is referred to as sensory marketing: marketing that influences consumers' perception of brands by using multi-sensory experiences to establish positive emotional connections with them (Williams, 2018). Sense marketing is defined as marketing management refers to the pattern of consumer sensory experiences associated with a product or brand. Indicators of marketing sense in this study are: sight, sound, and touch.

\section{Think Marketing}

Think marketing applications to the intellect, with the objective of creating cognitive, problem-solving experiences that engage customers creatively (Schmitt, 1999). Marketing that focuses on experiences arising from consumer (cognitive) reasoning. Through the process of creating new ideas, consumers evaluate their company or brand (Maghnati et al., 2012). Think marketing means marketing management refers to the consumer experience gained through the process of thinking and creativity. Some recipes to achieve success in think campaigns, including through: surprise, intrigue, and provocation (Schmitt, 1999).

\section{Research Framework}

Research variables have a recursive causal relationship, it can be seen from a variety of relevant research results. Sense marketing has a significant effect on customer satisfaction (Dian, 2018; Tetanoe \& Dharmayati, 2014). Sense marketing influences consumer repurchase intentions (Palupi, 2018; Amelia, 2017; Putri et al., 2020).

Think marketing effect on consumer satisfaction (Tetanoe \& Dharmayati, 2014; Indrawati \& Fatharani, 2016). Think marketing is an effort that needs to be created so that consumers are positively thinking about products or services after consumers feel good. This can create customer satisfaction in the longer term (Andreani, 2007).

The experience of think has a significant effect on repurchase intention. (Ong , 2017; Yossie et al., 2019; Amelia, 2017; Hendarsono \& Sugiharto, 2013).

Repurchase interest is consumer's willingness and action to repurchase a product, because of the satisfaction received from a product (Nurhayati dan Murti, 2012; Griffin, 2005; Yanti et al., 2019). When a customer is satisfied after buying or receiving a product, the intention to repurchase will appear (Firmawan Adixio \& Saleh, 2013). Causal relationships between variables are presented in Figure 1. 


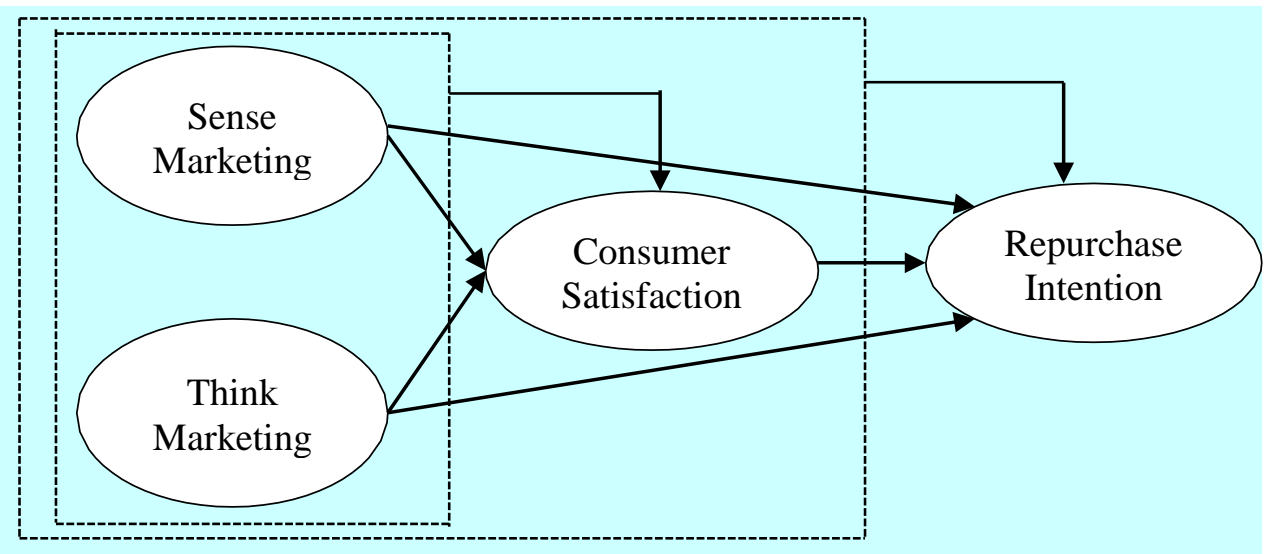

Source: Processed by Researchers, 2020

\section{Hypothesis}

Figure 1: Proposed Framework

The hypotheses of this research consist of: There is an effect of marketing sense on the satisfaction of vivo smartphone consumers in Medan; There is an effect of think marketing on customer satisfaction; There is an effect of customer satisfaction on repurchase intentions. There is an effect of marketing sense and think marketing simultaneously on customer satisfaction; There is an effect of marketing sense, think marketing, and customer satisfaction simultaneously on customer repurchase intentions.

\section{RESEARCH METHODOLOGY}

The research model consists of 4 variables namely sense marketing, think marketing, customer satisfaction, and repurchase intentions. Operationalization of variables produces 14 indicators. Observed variables were measured ordinally with a Likert scale of 1-7. The population includes the Medan city population which is spread across 21 districts; 15-64 years old; Vivo brand smartphone users and have made repeat purchases for the same brand,

The number of samples based on the maximum likelihood method with asymptotic covariance matrix, namely: $n \geq 1 / 2 \mathrm{~K}(\mathrm{~K}+1)$ where $\mathrm{K}$ is the number of manifest variables (Jöreskog , 2016). Another opinion says the number of multivariate model samples between $\mathrm{n} \times 5$ to $\mathrm{n} \times 10$, where $\mathrm{n}$ is the number of variables observed (Hair et al., 2009). Referring to the operationalization of variables there are 14 indicators. The number of samples in this study were $(14 * 10)$ or 140 people.

Primary data is collected through a questionnaire (google form). The distribution of the number of respondents is proportional to the number of residents in each district in Medan. Questionnaire Submission is accidental techniquely. Structural equation model (SEM) robust maximum likelihood method is used to process raw data. The initial step is to build the underlying theory. Test the factor loading indicator for each variable, test the validity and reliability of the measurement model. Parameter identification, discriminant validity, GOF test, and structural model modification.

\section{Results}

The reliability of the four measurement models can be seen from the validity of the indicators and the reliability of the variables (composite reliability and variance extract) Standardized loading factor of sight $=0.81$; sound $=0.83$; Touch $=0.86$; Surprise $=0.79$; Intrigue $=0.96$; Provocation $=0.75$; Telling good things $=0.76$; Pay less attention to other brands $=0.91$; Buy other products from the same company = 0.74; Transactional interest $=0.83$; Reference interest $=0.86$; Preferential interest $=0.89$; Explorative interest $=0.84$. All indicators of measurement models have ideal validity as measured by standardized loading factors $(\geq 0.70)$ (Hair et al., 2006). 
Sense marketing variables have composite reliability $=0.87$ and variance extract $=$ 0.70. Think marketing has composite reliability $=0.88$ and variance extract $=0.70$. Consumer satisfaction has composite reliability $=0.85$ and variance extract $=0.65$. Repurchase intention has composite reliability $=0.92$ and variance extract $=0.73$. All variables are reliable, shown by Composite Reliability $>0.70$ and Variance Extract $>$ 0.50 (Bollen, 1989).

Modified structural models are presented in the path diagram form. Look at Figure 2. The structural equation of path diagram above is: Satis $=0.69$ Sense + 0.22Think, $\mathrm{R}^{2}=0.79$ and Repur $=0.67$ Satisfaction +0.17 Sense +0.12 Think, $\mathrm{R}^{2}=0.77$. The overall structural model is good fit where the Chi-Square Probability (P) SatorraBentler formula $=0.27$; Goodness-of-fit Index $(\mathrm{GFI})=0.90$; Root mean square error of approximation $($ RMSEA $)=0.03$; Expected cross validation index $($ ECVI $)$

$=0.94$; Adjusted Goodness of Fit Index $(\mathrm{AGFI})=0.84$; Normed Fit Index $(\mathrm{NFI})=0.98$; Comparative Fit Index $(\mathrm{CFI})=1.00$; Parsimony Goodness of Fit Index $(\mathrm{PGFI})=$ 0.56; Parsimonious Normed Fit Index (PNFI) $=0.72$. Both exogenous variables have a covariance of $0.84<0.90$, meaning discriminant validity is good. There are no indicators that cross to other variables (no crossloading).

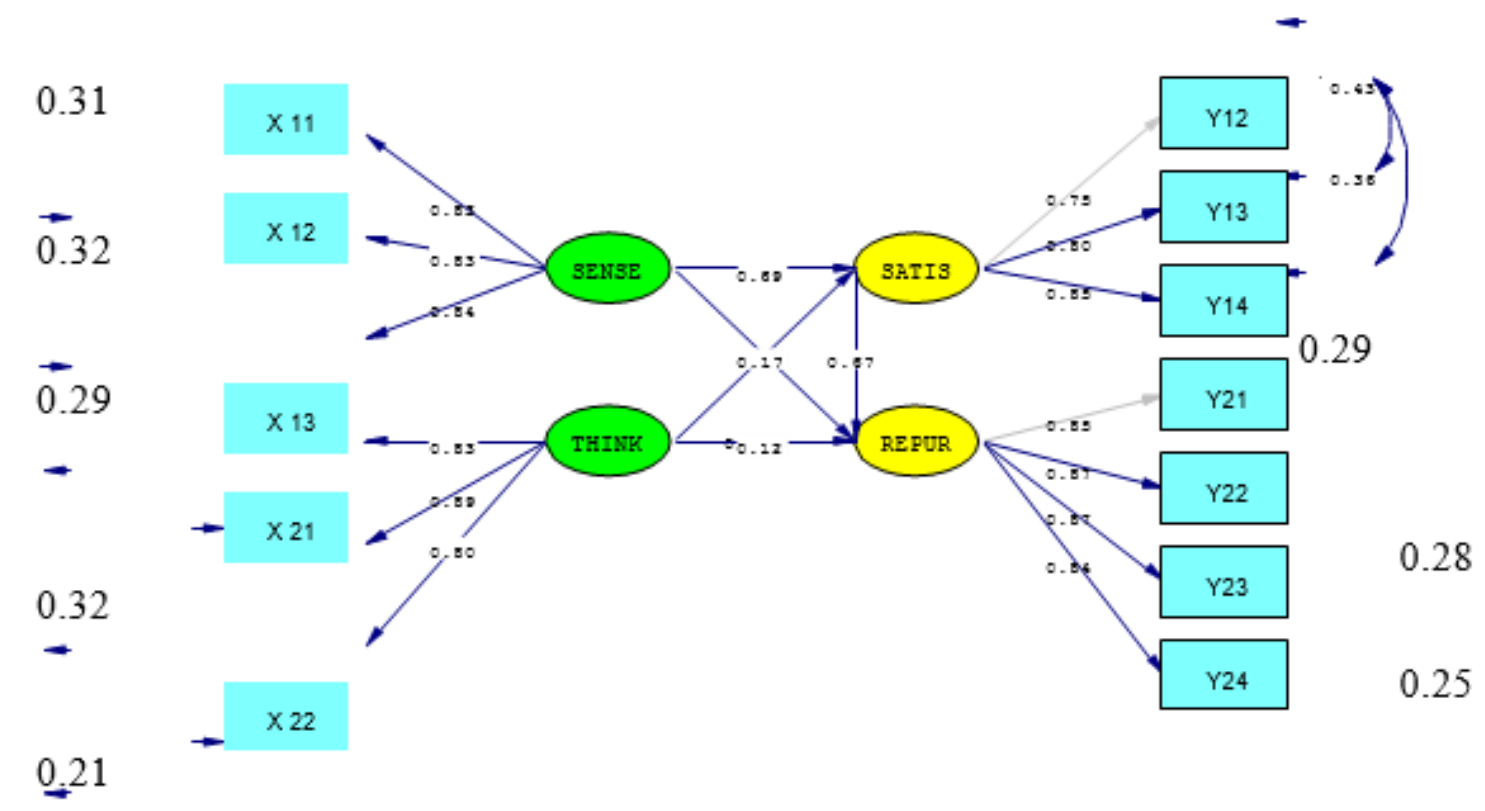

Chi-Square $=63.18, \mathrm{df}=57, \mathrm{P}$-value $=0.26723, \mathrm{RMSEA}=0.028$

Source: Processed by Researchers , 2020

Figure 2: Hibryd model's Path diagram

\section{Discussions}

The highest marketing sense is reflected by touch with a standardized loading factor of 0.83 greater than the other two indicators. The touch aspect has more role in marketing sense. The intrigue of think marketing is highest among the three indicators, standardized loading factors 0.96. Paying less attention to other brands is a major reflection of customer satisfaction. The standardized loading factor is 0.91 . Repurchase intention is reflected most highly by preferential interest with a standardized loading factor of 0.89 .

Sense marketing affects directly, significantly and in the direction of consumer satisfaction. Changes in this variable will have direct implications with changes in customer satisfaction. Increased marketing sense will have an impact on increasing vivo smartphone consumer satisfaction. The results of this study are in line with (Alkilani et al., 2012; Dian, 2018; Tetanoe \& Dharmayati, 2014). Marketing sense effect directly on 
repurchase intention significantly and in the same direction. This conclusion is supported by the results of the study (Putri et al., 2020; Palupi, 2018; Amelia, 2017). Improved consumer experience gained through sense (sight, hearing, and touch) will increase their repurchase intentions on vivo smartphones. The difference with the same variables in other studies is that it involves taste and smell. The direct effect of consumer satisfaction on repurchase intention is in the same direction and significant. If consumers are satisfied immediately will have the intention to repurchase. This finding is in line with the results of the study (Mohamed, 2014; Suandana et al., 2016; Nurhayati dan Murti, 2012; Griffin, 2005; Yanti et al., 2019). Increasing marketing sense directly increases consumer satisfaction, which in turn increases customer repurchase intentions. The repurchase indicator is excluded from the customer satisfaction variable because it is not ideal. So it is not the same content with the variable customer satisfaction with similar research. Think marketing has an effect on customer satisfaction but it is not significant. Therefore this influence cannot be generalized, even some authors call it no effect. The consumer experience gained through surprises, intrigue, and provocation carried out by the vivo smartphone company was not significantly satisfying consumers. The unsignificant impact of think marketing on satisfaction continues to the insignificant effect of this variable on repurchase intention.

The indirect effect of sense marketing on intention to repurchase is direct and significant with a coefficient of 0.47 . The total effect of sense marketing on repurchase intention is in the same direction and significant with a coefficient of

0.64. Consumer satisfaction is a mediating for sense marketing to repurchase intentions of 0.73 or $73 \%$ (strong). The direct effect coefficient of think marketing on satisfaction is 0.67 . The direct effect of marketing sense is stronger on customer satisfaction compared to repurchase intentions.

The indirect effect of think marketing on repurchase intention through customer satisfaction has a coefficient of 0.15 , in the same direction but not significant. In this context consumer satisfaction is not intervening in a causal relationship between think marketing and repurchase intentions. The direct effect coefficient of think marketing on customer satisfaction is 0.22 . The direct effect of think marketing on repurchase intentions was 0.26 . Although not significantly the direct effect of think marketing is higher than satisfaction.

The application of sense and think marketing simultaneously to consumer satisfaction in vivo smartphones has a determinant coefficient of 0.79 or $79 \%$. The $79 \%$ satisfaction variance was contributed by its predictors namely sense and think marketing. The remaining $21 \%$ is contributed by other factors outside the model. The role of the two variables on the satisfaction variance is far greater than the factors outside the model. If the three variables namely sense marketing, think marketing, and satisfaction are applied concurrently to repurchase intentions, the coefficient of determination is 0.77 . In this context, changes in the variance of repurchase intentions are determined by its predictors of $77 \%$. The remaining $23 \%$ comes from elements outside the model. The role of the three variables together contributes far more than factors outside the model.

\section{Conclusion}

This research focuses to identify and analyzing the effect of sense marketing and think marketing on consumer satisfaction and repurchase intention for vivo smartphone customers in Medan. Adult respondent who has made a repeat purchase. The analysis technique uses structural equation models with robust maximum likelihood. The most important indicator of sense marketing is touch. 
Dominant think marketing is reflected by intrigue. Sense marketing has a significant effect on customer satisfaction and intention to repurchase vivo smartphones. Think marketing has no significant effect on customer satisfaction and repurchase intentions. Consumer satisfaction has a significant effect on repurchase intentions. The influence of sense marketing is more powerful on satisfaction than on repurchase intentions. Consumer satisfaction is a mediating for sense marketing towards repurchase intentions. The contribution of its predictor to each dependent variable is good. Through this research vivo management is suggested to increase consumer satisfaction and repurchase intentions through the experience that consumers gain from touch and intrigue. This research is limited to two exogenous variables namely sense and think marketing. Future research is expected to add other variables related to the causal relationship with satisfaction and repurchase intention.

\section{REFERENCES}

Alkilani, K., Ling, K. C., \& Abzakh, A. A. (2012). The influence of experiential marketing and customer satisfaction on customer commitment . Asian Social Science, 9(1), 262270. https://doi.org/10.5539/ass.v9n1p262

Amelia, W. R. (2017). Pengaruh Experiental Marketing Terhadap Minat Beli Ulang Pelanggan Pada Rumah Makan Beringin Indah Pematang Siantar. 4(1), 50-60. https://doi.org/10.1037/a0015270.Timeline

Bollen Kenneth A. (1989). Structural Equations with Latent Variables. John Wiley \& Sons, Inc. https://doi.org/DOI:10.1002/9781118619179

Dian, F. R. Y. S. R. (2018). Analisis Pengaruh Experiential Marketing Terhadap Loyalitas Melalui Kepuasan Nasabah Sebagai Variabel Intervening (Studi Pada PT BRI Syariah Cabang Malang). Seminar Nasional Dan Call for Paper: Manajemen, Akuntansi Dan Perbankkan 2018| 74, 74-90.

Ferdinand Augusty. (2000). Structural equation modeling dalam penelitian manajemen aplikasi model-model rumit dalam penelitian untuk tesis $S-2$ \& disertasi $S-3$. Badan Penerbit Universitas Diponegoro. https://onesearch.id/Record/IOS1.INLIS000000000285683

Firmawan Adixio, R., \& Saleh, L. (2013). Pengaruh Kualitas Layanan Dan Nilai Yang Dirasakan Terhadap Niat Pembelian Ulang Melalui Mediasi Kepuasan Pelanggan Journal of Business and Banking, 3(2), 151. https://doi.org/10.14414/jbb.v3i2.233

Fransisca Andreani. (2007). Experiential Marketing (Sebuah Pendekatan Pemasaran). Jurnal Manajemen Pemasaran, 2(1), 1-8. http://puslit2.petra.ac.id/ejournal/index.php/mar/article/view/17009

Griffin, J. (2005). Customer loyalty: menumbuhkan dan mempertahankan kesetiaan pelanggan (Y. S. R. M. W. C. Kristiaji (ed.); Revised Ed). Erlangga. http://lib.ui.ac.id/detail.jsp?id=137221

Hair Joseph F. Jr, William C. Black, Barry J Babin, R. E. A. (2006). Mutivariate Data Analysis (New Jersey). Pearson Prentice Hall. https://www.researchgate.net/publication/234021554_Mutivariate_Data_Analysis

Hair Joseph F. Jr, William C. Black, Barry J Babin, R. E. A. (2009). Multivariate Data Analysis (7 edition). Pearson. https://www.amazon.com/Multivariate-DataAnalysis- Joseph-Hair/dp/0138132631

Hendarsono, G., \& Sugiharto, S. (2013). Analisis Pengaruh Experiental Marketing terhadap Minat Membeli kembali Konsumen. Jurnal Manajemen Pemasaran, 1(2), 1-8.

http://publication.petra.ac.id/index.php/manajemen-

pemasaran/article/view/524/458 Indrawati, \& Fatharani, U. S. (2016). the 
Effect of Experiential Marketing Towards

Customer. Asia Pacific Journal of Advanced Business and Social Studies, 2(2), $232-$

241. https://apiar.org.au/wp-content/uploads/2016/04/ICABSS_BRR771_BIZ227- 236.pdf

Jessica, H. T. P. B. B. J. D. T. F. (2005). Delighted Consumers Buy Again. Journal of Consumer Satisfaction, Dissatisfaction and Complaining Behavior, 18. https://jcsdcb.com/index.php/JCSDCB/article/view/57

Jöreskog Wallentin, K. G. U. H. O. Y. (2016). Multivariate Analysis with LISREL. Springer, Cham. https://doi.org/https://doi.org/10.1007/978-3-319-33153-9

Juniwati, J. (2015). Pengaruh Perceived Ease of Use, Nikmat dan Kepercayaan Terhadap Repurchase Intention dengan Customer Satisfaction Sebagai Intervening pada Belanja Online. Jurnal Ekonomi Bisnis Dan Kewirausahaan, 4(1), 140. https://doi.org/10.26418/jebik.v4i1.11465

Kertajaya; Hermawan. (2004). Hermawan Kartajaya on Positioning. Mizan Pustaka. https://books.google.co.id/books/about/Hermawan_Kartajaya_on_Positioning.htm 1?h l=id\&id=QcO-YCB6vk0C\&redir_esc $=y$

Kotler Philip ; Keller Lane Kevin. (2012). Marketing management (14th editi). Prentice Hall. https://www.worldcat.org/title/marketing-management/oclc/678924608

Lamongi, J., Loindong, S. S. R., Sam, U., \& Manado, R. (2018). Pengaruh Experiential Marketing Terhadap intensi membeli kembali Konsumen Di J.Co Donuts Dan Coffee Manado Town Square. Jurnal EMBA: Jurnal Riset Ekonomi, Manajemen, Bisnis Dan Akuntansi, 6(4), 3038-3047. https://doi.org/10.35794/emba.v6i4.21217

Maghnati, F., Ling, K. C., \& Nasermoadeli, A. (2012). Exploring Relationships between Experiential Marketing and Experiential Value. International Business Research, 5(11), 169-177. https://doi.org/10.5539/ibr.v5n11p169

Mohamed , Ramlah Hussein , Nurul Hidayah Ahmad Zamzuri , Hanif Haghshenas , Ramlah Hussein , Nurul Hidayah Ahmad Zamzuri, H. H. (2014). Insights into individual's online shopping continuance intention. Industrial Management \& Data Systems, 114(9). https://www.emerald.com/insight/content/doi/10.1108/IMDS-07- 20140201/full/html

Nurhayati Wahyu Wijaya Murti. (2012). Analisis Faktor yang mempengaruhi Minat Beli Ulang Masyarakat Terhadap Produk handphone. Value Added, 8(2). https://doi.org/10.1017/CBO9781107415324.004

Ong Yinyin Widyanata, D. S. (2017). Analisis Pengaruh Experiential Marketing Terhadap Minat Beli Ulang Konsumen. Jurnal Hospitality Dan Manajemen Jasa, 5(1), 1689-1699. https://doi.org/10.1017/CBO9781107415324.004

Palupi Nurul Dilah. (2018). The impact of sensory marketing on customer satisfaction and repurchase intention (Study case in Grand Kartika Hotel Restaurant in Pontianak). Jurnal Manajemen Update, 7(2). http://jurnal.untan.ac.id/index.php/ejmfe/article/view/28609

Putri, K. C., Furkan, L. M., Ekonomi, F., Bisnis, D., \& Mataram, U. (2020). Elastisitas - Jurnal Ekonomi Pembangunan Pengaruh Experiential Marketing Terhadap Minat Berkunjung Ulang Kon- sumen Mcdonald 's Sriwijaya Elastisitas - Jurnal Ekonomi Pembangunan. Elastisitas, 2(1), 100-123. https://elastisitas.unram.ac.id/index.php/elastisitas/article/view/24/33

Schmitt, B. H. (1999). Experiential Marketing: A New Framework for Design and Communications By Bernd Schmitt. Design Management Review, 10(2). https://doi.org/10.1111/drev.10298 
Suandana, N., Rahyuda, K., \& Yasa, N. (2016). Pengaruh Pengalaman Membeli Produk Fashion pada intensi Membeli Kembali Melalui Kepuasan Dan Kepercayaan Pelanggan. Matrik:Jurnal Manajemen, Strategi Bisnis Dan Kewirausahaan, 10(1), 85-97.

Tetanoe, V. R., \& Dharmayati, D. (2014). Pengaruh Experiential Marketing Terhadap Pembelian Ulang Dengan Kepuasan Konsumen Sebagai Variable Intervening. Jurnal Manajemen Pemasaran, 2(1), 1-12.

Thamrin Abdullah, F. T. (2012). Manajemen pemasaran. PT Raja Grafindo Persada. https://scholar.google.co.id/citations?user=wxKxmd4AAAAJ\&hl=id\#d=gs_md_ci ta-

$\mathrm{d} \& \mathrm{u}=\% 2$ Fcitations\%3Fview_op\%3Dview_citation\%26hl\%3Did\%26user\%3Dwx $\mathrm{Kx}$ md4AAAAJ\%26citation_for_view\%3DwxKxmd4AAAAJ\%3A2osOgNQ5qMEC $\% 2$ 6tzom\%3D-420

Tjiptono, F. (2014). Pemasaran Jasa: Prinsip, Penerapan, dan Penelitian. Andi Offset.

https://scholar.google.com.my/citations?user=fQLNcNUAAAAJ\&hl=en\#d=gs_m d_c ita-

$\mathrm{d} \& \mathrm{u}=\% 2$ Fcitations\%3Fview_op\%3Dview_citation\%26hl\%3Den\%26user\%3DfQ LN

cNUAAAAJ\%26citation_for_view\%3DfQLNcNUAAAAJ\%3AufKn5pxu7C0C\% $26 \mathrm{t}$ zom\%3D-420

Toko vivo di Sumatera Utara. (2020). Google. https://www.google.com/search?safe=strict\&client=firefox-b$\mathrm{d} \& \mathrm{tbm}=\mathrm{lcl} \& \mathrm{sxsrf}=\mathrm{ALeKk03RZRrFL5uE63oJ} 1 \mathrm{e} 60 \mathrm{z} 1 \mathrm{uRIw}-$ v4g\%3A1594914281420\&ei=6XUQX4qvGZK88QOa5oiQCw\&q=TOKO+VIVO $+\mathrm{D}$

I+SUMATERA+UTARA\&oq=TOKO+VIVO+DI+SUMATERA+UTARA\&gs_1 $=$ ps $\mathrm{y}$-ab.12...21696.25001.0.29161.0.0.0

Williams Alicia. (2018). The Five Senses of Marketing: How to Utilize Sensory Marketing.

Aliste Marketing. https://alistemarketing.com/blog/5-senses-sensorymarketing/ Yanti Febrini, I., Widowati PA, R., \& Anwar, M. (2019). Pengaruh Experiential Marketing Terhadap Kepuasan Konsumen Dan Minat Beli Ulang Di Warung Kopi Klotok, Kaliurang, Yogyakarta. Jurnal Manajemen Bisnis, 10(1), 35-54. https://doi.org/10.18196/mb.10167

Yossie, Rossanty Rahima br Purba, Firman Ario, Muhammad Dharma Tuah Putra Nasution,*, I. S. (2019). Impact of Experiential Marketing on Customers Repurchase Intention in Gempita Cafe. Proceedings of The 2nd International Conference On Advance And Scientific Innovation, ICASI 2019, 18 July, Banda Aceh, Indonesia.

Yusuf, O. (2019, September 2). Mengamati Pergeseran Pasar Smartphone Indonesia di 2019. Kompas.Com. https://tekno.kompas.com/read/2019/09/02/14010097/mengamati-pergeseran-pasarsmartphone-

Zahri, A., Wahab, Z., \& Widiyanti, M. (2019). The Effect Of Experiential Marketing On Customer Satisfaction At CGV Cinema In Palembang. International Journal of Scientific and Research Publications (IJSRP), 9(12), p9675. https://doi.org/10.29322/ijsrp.9.12.2019.p9675 